\title{
EVALUATION OF THE ENERGY SAVING MEASURES EFFECTIVENESS IN THE PRODUCTION, TRANSPORTATION AND CONSUMPTION OF THERMAL ENERGY IN THE COMMUNAL SECTOR
}

\author{
Polyvianchuk A. P., Semenenko R. A., \\ Romanenko S. V., Semenenko L. V.
}

\section{INTRODUCTION}

The use of systems communal energy is accompanied by a significant negative impact on the environment, which is primarily associated with emissions of greenhouse gases and pollutants into the atmosphere, contributes to the development and strengthening of local and global environmental problems ${ }^{1}$ : the greenhouse effect, the destruction of the ozone layer of the atmosphere, acid rain, deterioration environmental quality, etc. On the other hand, the operation of communal boiler houses requires providing fuel, the need for which is growing with the expansion of heating networks. In this regard, in the face of an increase in the negative impact of thermal energy facilities on the environment and an increase in energy prices, the problem of increasing the environmental and energy safety sector of communal heat is highly relevant. A new approach to solving this problem is to combine the producer, supplier and consumer of thermal energy into a single complex technical system for which the search for optimal technical solutions to increase its environmental, energy and economic efficiency is carried out ${ }^{2}$. To implement this approach, a theoretical base should be created that will provide for carrying out multicriteria evaluation of the effectiveness of energy conservation measures at facilities that produce, transport and consume thermal energy.

The purpose of this work was to create and confirm the practical applicability of mathematical models for a comprehensive assessment of the energy, environmental and economic efficiency of energy conservation

\footnotetext{
${ }^{1}$ Варламов Г.Б., Любчик Г.М., Маляренко В.А. Теплоенергетичні установки та екологічні аспекти виробництва енергії : підручник. Київ : ІВЦ «Видавництво «Політехніка», 2003. 232 с.

${ }^{2}$ Polyvianchuk A., Belousov I., Semenenko R. Development and implementation methods multicriteria evaluation of efficiency energy saving activities in the field of heat supply. Modern engineering research: topical problems, challenges and modernity : Collective monograph. Riga : Izdevnieciba «Baltija Publishing», 2020. P. 370-396. DOI: 10.30525/978-9934-588-47-1.17.
} 
measures recommended for the implementation of thermal energy in the public utilities in a complex technical system "producer-supplier-consumer". To achieve this goal, the following tasks were solved:

1) the development of mathematical models to assess the energy efficiency of energy-saving measures that are implemented at the facilities that produce, transport and consume thermal energy in the communal sector;

2) the creation of a mathematical model for a comprehensive assessment of the effectiveness of energy-saving measures according to the criteria of energy, environmental and economic effects;

3) confirmation of the practical suitability of the developed mathematical models during the research of the full-scale object of the complex technical system "producer-supplier-consumer" of thermal energy.

Below are the results of solving these problems.

\section{Mathematical models for evaluating the effectiveness of energy-saving means in the production of thermal energy \\ 1.1. Determining the energy efficiency of using a heat pump for heating buildings}

The initial data for the calculation are determined by the results of a fullscale survey or design parameters of buildings, their purpose, climatic conditions, and standard values of the temperature of indoor air in buildings. The list of necessary data for the calculation are given in table 1 .

Energy expenses for heating for the heating season Q (in J), are determined by the formula:

$$
\mathrm{Q}=\sum_{i=1}^{7} Q_{\text {monthi }},
$$

where $\mathrm{Q}_{\text {monthi }}$ - energy expenses for heating by periods (7 months) of the heating season - for October, November, December, January, February, March and April.

Energy expenses for heating for each of the months of the heating season are determined by the formulas.

Table 1

The source data for calculating the energy efficiency of the activity

\begin{tabular}{|c|l|c|c|}
\hline № & \multicolumn{1}{|c|}{ Parameter Name } & Unit & $\begin{array}{c}\text { Desig- } \\
\text { nation }\end{array}$ \\
\hline 1 & \multicolumn{1}{|c|}{2} & 3 & 4 \\
\hline 1 & Total wall area & $\mathrm{M}^{2}$ & $\mathrm{~F}_{\mathrm{w}}$ \\
\hline 2 & Thickness of the i-th layer of walls & $\mathrm{M}$ & $\mathrm{h}_{\mathrm{wi}}$ \\
\hline
\end{tabular}


Table 1 (ending)

\begin{tabular}{|l|l|c|c|}
\hline 1 & \multicolumn{1}{|c|}{2} & \multicolumn{1}{|c|}{} & \multicolumn{1}{|c|}{4} \\
\hline 3 & Material of the i-th layer of walls & - & - \\
\hline 4 & The total area of window openings & $\mathrm{m}^{2}$ & $\mathrm{~F}_{\mathrm{win}}$ \\
\hline 5 & Glass thickness in window openings & $\mathrm{m}$ & $\mathrm{h}_{\mathrm{wini}}$ \\
\hline 6 & The number of glasses in the window openings & $\mathrm{pcs}$ & - \\
\hline 6 & The total area of attic floors & $\mathrm{m}^{2}$ & $\mathrm{~F}_{\mathrm{f}}$ \\
\hline 7 & The thickness of the i-th layer of attic floors & $\mathrm{m}$ & $\mathrm{h}_{\mathrm{afi}}$ \\
\hline 8 & Material of the ith layer of attic floors & - & - \\
\hline 9 & Total floor area & $\mathrm{m}^{2}$ & $\mathrm{~F}_{\mathrm{f}}$ \\
\hline 10 & The thickness of the i-th floor layer & $\mathrm{m}$ & $\mathrm{h}_{\mathrm{fi}}$ \\
\hline 11 & Material of the i-th floor layer & - & - \\
\hline 12 & $\begin{array}{l}\text { Monthly average temperatures outdoor air for the } \\
\text { periods of the heating season }\end{array}$ & ${ }^{\circ} \mathrm{C}$ & $\mathrm{t}_{\mathrm{month}}$ \\
\hline 13 & Necessary room temperature & ${ }^{\circ} \mathrm{C}$ & $\mathrm{t}_{\mathrm{in}}$ \\
\hline 14 & Duration of periods (months) of the heating season & $\mathrm{h}$ & $\tau_{\mathrm{i}}$ \\
\hline 15 & Ceiling Height Indoors & $\mathrm{m}$ & $\mathrm{h}$ \\
\hline
\end{tabular}

$$
Q_{\text {monthi }}=\Delta t_{\text {month }} \cdot \sum_{i=1}^{4}\left(3600 \cdot k_{i} \cdot F_{i}+c \cdot m_{\mathrm{inf}}\right)
$$

where $\Delta \mathrm{t}_{\text {monthi }}\left({ }^{\circ} \mathrm{C}\right)$ is the difference between the room temperature and the average monthly outdoor temperature in the corresponding period of the heating season; the outdoor temperature in each of the months of the heating season is set in accordance with the climatic characteristics of the territory of the object of study; the outdoor temperature in the corresponding period of the heating season for the climatic conditions of Kharkov can be taken according to the table 2, the air temperature in the room - table 3;

$\mathrm{k}_{\mathrm{i}}\left(\mathrm{W} /\left(\mathrm{m}^{2} \mathrm{~K}\right)\right)$ - heat transfer coefficients of elements of the fencing structures, including external walls, windows, floors, ceiling, is determined by the formula (3);

$F_{i}\left(m^{2}\right)$ - the area elements of the fencing structures, including external walls, windows, floors, and ceilings; adopted in accordance with table 1;

$\mathrm{c}(\mathrm{J} /(\mathrm{kg} \mathrm{K}))$ - the mass heat capacity of air, in the calculations the value $\mathrm{c}=1005 \mathrm{~J} /(\mathrm{kg} \mathrm{K})$ is approximately taken;

$\mathrm{m}_{\text {inf }}(\mathrm{kg})$ - the mass of air entering the room with infiltration per hour is determined by the formula (4);

$\tau_{\mathrm{i}}(\mathrm{h})$ - the duration of the corresponding period of the heating season; it is taken in accordance with the table 2 . 
Table 2

Values of the average monthly temperature outdoor air of the periods (months) of the heating season for the climatic conditions of Kharkov ${ }^{3}$

\begin{tabular}{|c|c|c|c|c|c|c|c|c|}
\hline Characteristic & $t_{10}$ & $\mathrm{t}_{11}$ & $t_{12}$ & $\mathrm{t}_{1}$ & $t_{2}$ & $t_{3}$ & $\mathrm{t}_{4}$ & 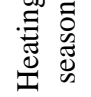 \\
\hline $\begin{array}{l}\text { The duration period } \\
\text { of the heating } \\
\text { season, hours }\end{array}$ & 336 & 720 & 744 & 744 & 672 & 744 & 336 & 4296 \\
\hline \begin{tabular}{|l|} 
Monthly average \\
temperatures \\
outdoor air, ${ }^{\circ} \mathrm{C}$
\end{tabular} & $+7,5$ & $+1,0$ & $-3,7$ & $-5,9$ & $-5,1$ & 0,0 & $+9,0$ & $-1,0$ \\
\hline
\end{tabular}

The heat transfer coefficient of elements of fencing structures, including external walls, windows, floors, ceiling $\mathrm{k}_{\mathrm{i}}, \mathrm{W} / \mathrm{m}^{2} \mathrm{~K}$ is determined by the formula ${ }^{4}$.

\section{Table 3}

The calculated values of temperature and humidity air of the building ${ }^{5}$

\begin{tabular}{|c|l|c|c|}
\hline № & \multicolumn{1}{|c|}{ Building use } & $\begin{array}{c}\text { Temperature } \\
\text { indoor air, }{ }^{\circ} \mathrm{C}\end{array}$ & $\begin{array}{c}\text { Relative } \\
\text { humidity, } \%\end{array}$ \\
\hline 1 & Residential buildings & 20 & 55 \\
\hline 2 & Public and administrative buildings & 20 & 60 \\
\hline 3 & $\begin{array}{l}\text { Medical and children's educational } \\
\text { institutions }\end{array}$ & 21 & 50 \\
\hline 4 & Preschool institutions & 22 & 50 \\
\hline
\end{tabular}

$$
k_{i}=\frac{1}{\frac{1}{\alpha_{i n}}+\sum_{i=1}^{n}\left(\frac{h i}{\lambda i}\right)+\frac{1}{\alpha_{\text {out }}}} \text {, }
$$

where $\alpha_{\text {in }}\left(\mathrm{W} /\left(\mathrm{m}^{2} \mathrm{~K}\right)\right)$ - the heat transfer coefficient from the wall to the air inside the room; accepted in the calculations $\alpha_{\text {in }}=8.3 \mathrm{~W} / \mathrm{m}^{2} \mathrm{~K}$;

${ }^{3}$ ДСТУ-Н Б В.1.1-27: 2010. Будівельна кліматологія. [Чинний від 2011-11-01]. Київ : Мінрегіонбуд України, 2011. 127 с.

${ }^{4}$ Исаченко В.П., Осипова А.С., Сукомел В.А. Теплопередача : учебник для вузов. Москва : Энергия, 1975. 488 с.

5 ДБН В.2.6-31: 2016. Теплова ізоляція будівель. [Чинний від 2017-04-01]. Київ : Мінрегіон України, 2017. 31 с. 
$\alpha_{\text {out }}\left(\mathrm{W} /\left(\mathrm{m}^{2} \mathrm{~K}\right)\right)$ - heat transfer coefficient from the wall to the outside air. It is taken in accordance with the table 4;

$h_{i}(m)-$ the thickness of the $\mathrm{i}$-th layer of the fencing construction. It is taken in accordance with the table 1 ;

$\lambda_{\mathrm{i}}(\mathrm{W} /(\mathrm{m} \mathrm{K}))$ - thermal conductivity coefficient of the i-th layer of the fencing construction. It is taken depending on the material of manufacture of the layer of the protective structure correspond of the table 5;

$\mathrm{n}$ - the number of layers of the fencing construction. It is taken in accordance with the table 1 .

The mass of air entering the room with infiltration per hour of the heating season:

$$
m_{\mathrm{inf}}=n \cdot h \cdot F_{a} \cdot \rho,
$$

where $\mathrm{n}(1 / \mathrm{h})$ - the multiplicity air exchange (table 6$)$;

$\mathrm{F}_{\mathrm{a}}\left(\mathrm{m}^{2}\right)$ - the total area of the room (table 1);

$\mathrm{h}(\mathrm{m})$ - the height of the ceilings in the room (table 1);

$\rho\left(\mathrm{kg} / \mathrm{m}^{3}\right)$ - air density in the room; accepted $\rho=1.2 \mathrm{~kg} / \mathrm{m}^{3}$.

Table 4

The value of the coefficient of heat transfer from walls, attic floors, floors to the outside air $^{6}$

\begin{tabular}{|c|l|c|}
\hline No & \multicolumn{1}{|c|}{ Type of construction } & $\begin{array}{c}\text { Heat transfer } \\
\text { coefficient, } \\
\mathrm{W} /\left(\mathrm{m}^{2} \mathrm{~K}\right)\end{array}$ \\
\hline 1 & Exterior walls, overlap over driveways, windows & 23 \\
\hline 2 & Overlap over cold basements adjacent to cold air & 17 \\
\hline 3 & $\begin{array}{l}\text { Attic overlap and overlap over unheated } \\
\text { basements, not ventilated by outside air }\end{array}$ & 6 \\
\hline
\end{tabular}

After calculating the energy expenses for heating the house during the heating season $\mathrm{Q}$, we set measures to reduce energy expenses by using a heat pump. The use of heat pumps operating according to the air-water scheme is recognized as one of the modern technologies for building heat supply in world practice. Let us calculate the reduction in energy expenses using the Bosch WPL 17 AR heat pump as an example. The energy of $\mathrm{Q}_{\mathrm{hp}}$ (in J) was spent by the heat pump:

${ }^{6}$ ДСТУ Б В.2.6-189: 2013. Методи вибору теплоізоляційного матеріалу для утеплення будівель. [Чинний від 2014-01-01]. Київ : Мінрегіон України, 2014. 51 с. 


$$
Q_{h p}=\sum_{i=1}^{7} Q_{h p i}
$$

where $\mathrm{Q}_{\mathrm{hpi}}(\mathrm{J})$ - energy expenses for the operation of the heat pump in each of the periods (months) of the heating season:

$$
Q_{h p i}=\frac{Q_{i}}{\varepsilon_{i}},
$$

where $\varepsilon_{\mathrm{i}}$ - the power factor of the heat pump in each of the periods (months) of the heating season, which is determined by the empirical formula recommended by the enterprise the manufacturer of this equipment ${ }^{7}$ :

\section{The values of the coefficient of thermal conductivity of building materials}

\begin{tabular}{|c|l|c|}
\hline № & \multicolumn{1}{|c|}{ Material name } & $\begin{array}{c}\text { Thermal conductivity } \\
\text { coefficient, } \\
\lambda, \mathrm{W} /(\mathrm{m} \mathrm{K})\end{array}$ \\
\hline 1 & $\begin{array}{l}\text { Heat-insulating products on the basis of mineral wool } \\
\text { on the basis of basalt fiber }\end{array}$ & 0.05 \\
\hline 2 & Products from the made foam expanded polystyrene & 0.048 \\
\hline 3 & Plates from resolo-formaldehyde polyfoam & 0.06 \\
\hline 4 & Fibreboard and chipboard & 0.15 \\
\hline 5 & $\begin{array}{l}\text { Bricklaying ceramic on a cement-sandy solution from } \\
\text { a corpulent brick }\end{array}$ & 0.76 \\
\hline 6 & Laying brick ceramic on cement-sand mortar & 0.61 \\
\hline 7 & $\begin{array}{l}\text { Silicate brick masonry on cement-sand mortar of } \\
\text { solid brick }\end{array}$ & 0.84 \\
\hline 8 & Pine and spruce across the fibers & 0.16 \\
\hline 9 & Pine and spruce along the fibers & 0.32 \\
\hline 10 & Ferroconcrete & 1.98 \\
\hline 11 & Cement-sand mortar & 0.84 \\
\hline 12 & Window glass & 0.76 \\
\hline
\end{tabular}

$$
\varepsilon_{i}=\frac{0.5 \cdot T}{T-T_{0}},
$$

where $\mathrm{T}(\mathrm{K})$ - the temperature of the heated coolant at the outlet of the heat pump; $\mathrm{T}_{0}(\mathrm{~K})$ - temperature outdoor air.

7 Документация по проектированию Logatherm WPL...AR. URL: https://go-gl.com/jSjM8tGUb4. 
Table 6

Standard values of the multiplicity of air exchange

\begin{tabular}{|c|c|c|c|}
\hline № & Type of building & Energy efficiency class & $\mathrm{n}, 1 / \mathrm{h}$ \\
\hline \multirow{2}{*}{1} & $\begin{array}{l}\text { Residential, administrative, } \\
\text { educational, medical }\end{array}$ & $\mathrm{C}$ & 2.0 \\
\cline { 3 - 4 } & $\mathrm{B}$ & 1.0 \\
\hline \multirow{2}{*}{2} & $\begin{array}{l}\text { Public buildings other than } \\
\text { those specified in paragraph } \\
1\end{array}$ & $\mathrm{~A}$ & 0.8 \\
\cline { 2 - 3 } & $\mathrm{C}$ & 2.0 \\
\cline { 2 - 3 } & $\mathrm{B}$ & 1.0 \\
\hline
\end{tabular}

The temperature of the heated coolant at the outlet of the heat pump is set depending on the type of heat extraction system respectively table 7 .

Table 7

The temperature of the heated coolant at the outlet of the heat pump

\begin{tabular}{|l|l|c|}
\hline № & \multicolumn{1}{|c|}{$\begin{array}{c}\text { Application of heat extraction } \\
\text { system }\end{array}$} & $\begin{array}{c}\text { The temperature of the heated } \\
\text { coolant at the outlet of the heat } \\
\text { pump, } \mathrm{t},{ }^{\circ} \mathrm{C}\end{array}$ \\
\hline 1 & "Warm floor" contour & 35 \\
\hline 2 & $\begin{array}{l}\text { System of radiators under } \\
\text { window apertures }\end{array}$ & 55 \\
\hline
\end{tabular}

The energy savings for heating during the heating season as a result of measures to reduce heat loss where, $\mathrm{J}$ are defined as $\Delta \mathrm{Q}=\mathrm{Q}-\mathrm{Q}_{\mathrm{hp}}$.

\subsection{Determination of energy efficiency from the introduction of gas condensing boilers instead of traditional boilers}

To determine the resource (saving fuel consumption), economic and environmental efficiency of the introduction of gas condensing boilers instead of traditional boilers, define the annual volume level of reduction in fuel consumption arising from the introduction of such an event.

1. Determine the annual volume level of fuel consumption for the release of the planned amount of thermal energy when using traditional gas boilers.

The amount of fuel equivalent, which is necessary for the release of the total annual amount of heat is determined by the formula ${ }^{8}$ :

${ }^{8}$ КТМ 204 Україна 244-94. Норми та вказівки по нормуванню витрат палива та теплової енергії на опалення житлових та громадських споруд, а також на господарсько-побутові потреби України. Київ : ЗАТ «ВІПОЛ» ДК № 15, 2011. 376 с. 


$$
B_{\text {let }}^{\text {feNo1 }}=\frac{Q_{\text {let }}^{\text {year }}}{Q_{e f} \cdot\left(\eta_{b p}\right)_{m}} \cdot 100,
$$

where $\mathrm{B}^{\text {fe№ } 1}{ }_{\text {let }}-$ the amount of fuel equivalent for letting go the planned amount of thermal energy when using traditional (non-condensing) gas boilers, tons of f. e.;

$\mathrm{Q}^{\mathrm{year}}{ }_{\text {let }}$ - the total amount of heat released during the calendar year, Gcal;

$\mathrm{Q}_{\mathrm{ef}}$ - calorific value of equivalent fuel, equal to $7000 \mathrm{Kcal} / \mathrm{kg}$;

$\left(\eta_{\mathrm{bp}}\right)_{\mathrm{m}}$ - efficiency for heat supply for the entire boiler house equipped with traditional gas boilers during the release of the planned amount of thermal energy during the billing period (for example, the heating period, or the calendar year), $\%$.

The total amount of heat generated for example per year is defined as amount useful used heat per year, the heat loss in the heating networks, the heat loss for the boiler's own needs for the same period:

$$
Q_{\text {gea }}^{\text {year }}=Q_{u}^{\text {year }}+Q_{e h}^{\text {year }}+Q_{o n}^{\text {year }},
$$

where, $Q^{\text {year }}{ }_{u}$ - useful used by consumers thermal energy per calendar year, Gcal;

$Q_{\text {eh }}^{\text {year }}$ - loss of thermal energy in external heating networks for a calendar year, Gcal;

$\mathrm{Q}^{\mathrm{year}}$ on - consumption of heat energy for the boiler plant's own needs for a calendar year, Gcal.

The amount of heat released per year is determined as the sum of the heat used and losses in the heating networks:

$$
Q_{\text {let }}^{\text {year }}=Q_{u}^{\text {year }}+Q_{e h}^{\text {year }},
$$

Heat loss in heating networks $\mathrm{Q}^{\mathrm{year}}{ }_{\text {eh }}$ determined by commercial heat and heat consumption metering devices or by calculations.

The amount of useful heat used per year is defined as the sum of heat consumption for heating, ventilation and hot water supply (determined by commercial heat metering devices or by calculations):

$$
Q_{u}^{\text {year }}=Q_{h}^{\text {year }}+Q_{v}^{\text {year }}+Q_{h w s}^{\text {year }},
$$

where $\mathrm{Q}^{\mathrm{year}}{ }_{\mathrm{h}}$ - the heat consumption to meet the heating needs of consumers, Gcal;

$\mathrm{Q}^{\mathrm{year}}{ }_{\mathrm{v}}$ - the heat consumption to meet the ventilation needs of consumers, Gcal;

$\mathrm{Q}_{\text {hws }}^{\text {year }}$ - the heat consumption for meeting the needs of hot water supply to consumers, Gcal. 
Coefficient $\left(\eta_{\mathrm{bp}}\right)_{\mathrm{m}}$ determined by the formula:

$$
\left(\eta_{b p}\right)_{m}=\frac{Q_{1} \cdot \eta_{1}+Q_{2} \cdot \eta_{2}+\ldots+Q_{n} \cdot \eta_{n}}{\left(Q_{1}+Q_{2}+\ldots+Q_{n}\right) \cdot\left(1-\frac{k_{h l}}{100}\right)},
$$

where $\mathrm{Q}_{1}, \mathrm{Q}_{2}, \ldots, \mathrm{Q}_{\mathrm{n}}$ - the planned production of thermal energy during the year by each of the boilers, Gcal;

$\eta_{1}, \eta_{2}, \ldots, \eta_{\mathrm{n}}$ - the average annual gross efficiency, respectively, for each boiler (determined by individual operating cards or by passport data reduced to the actual average hourly power of each boiler during the calculation period);

$\mathrm{k}_{\mathrm{hl}}$ - the normative share of heat consumption for own needs of the boiler room, $\%$.

2. Let us determine the annual level of fuel consumption for dispensing the planned amount of thermal energy when using gas condensing boilers instead of traditional boilers.

The amount of conditional fuel, which is necessary for the production of the total annual amount of heat is determined by the formula:

$$
B_{\text {let }}^{\text {feNo2 }}=\frac{Q_{\text {let }}^{\text {year }}}{Q_{e f} \cdot\left(\eta_{b p}\right)_{m}} \cdot 100,
$$

where $\mathrm{B}^{\text {fe№ } 2}$ let - the amount of fuel equivalent, tons of f. e.;

$\mathrm{Q}^{\mathrm{year}}{ }_{\text {let }}$ - the total amount of heat released for the year, Gcal;

$\mathrm{Q}_{\mathrm{ef}}-$ calorific value of equivalent fuel, equal to $7000 \mathrm{Kcal} / \mathrm{kg}$;

$\left(\eta_{\mathrm{bp}}\right)_{\mathrm{m}}$ - efficiency for the entire boiler house equipped with gas condensing boilers for the production of thermal energy (according to individual operating cards or according to passport data reduced to the actual average hourly power of each boiler during the billing period), $\%$.

3 . The annual level of reduction volume in the consumption of equivalent fuel arising from the introduction of gas condensing boilers instead of traditional boilers $\Delta \mathrm{B}^{\mathrm{fe}}$ determined by the formula:

$$
\Delta B^{f e}=B_{\text {let }}^{f e \text { №1 }}-B_{\text {let }}^{f e \text { №2 }},
$$

4. Conversion of fuel equivalent to natural is performed according to the formula:

$$
B^{n f}=B^{f e} \cdot 10^{3} \cdot \frac{Q_{f e}}{Q_{n c v}},
$$

where $\mathrm{B}^{\mathrm{nf}}$ - total boiler room need for natural fuel to produce the planned amount of heat, $\mathrm{m}^{3}$; 
$\mathrm{B}^{\mathrm{fe}}$ - the same, in conditional fuel, tons of f. e.;

$\mathrm{Q}_{\mathrm{fe}}-$ the calorific value of equivalent fuel, which is $29309 \mathrm{~kJ} / \mathrm{kg}(7000$ $\mathrm{Kcal} / \mathrm{kg}$ );

$\mathrm{Q}_{\mathrm{ncv}}$ - the net calorific value of natural fuel, $\mathrm{Kcal} / \mathrm{kg}$ (the value of which is determined in accordance with the certificates of this fuel or the results of laboratory analysis).

This recalculation can be performed according to the formula:

$$
B^{n f}=\frac{B^{f e}}{K},
$$

where $\mathrm{K}=\mathrm{Q}_{\mathrm{ncv}} / \mathrm{Q}_{\mathrm{ef}}$ - the caloric equivalent equal to the ratio of the calorific value of natural fuel to the calorific value of standard fuel, the value of which is determined in accordance with the certificates of this fuel or the results of laboratory analysis.

\section{Mathematical model for evaluating the effectiveness of energy-saving means in the transportation of thermal energy}

Determination of energy efficiency from the introduction of preliminarily heat insulated pipes of external heating networks instead of pipelines in traditional insulation or pipelines without insulation.

1. The saved amount of thermal energy for the year $\Delta \mathrm{Q}$ from the introduction of preliminarily heat insulated pipes, shaped products and fittings in accordance with ДСТУ Б В.2.5-31: 2007 and the current regulatory documentation (ДБН B.2.5-39: 2008) is determined by the formulas:

$$
\Delta Q=Q_{t o t 1}-Q_{t o t 2},
$$

where $\mathrm{Q}_{\text {tot1 }}$ - total heat loss due to coolant cooling in pipelines of external heat networks heat insulated with traditional types of thermal insulation (mineral wool mats) and pipelines without thermal insulation, Gcal/year;

$\mathrm{Q}_{\text {tot2 }}$ - total heat loss due to coolant cooling in pipelines external heating networks heat insulated subject to implementation preliminarily thermally insulated pipes shaped products and fittings instead of traditional types of thermal insulation (mineral wool mats) and in pipeline sections did not have thermal insulation, Gcal/year.

$$
Q_{\text {tot } 1}=Q_{i s}+Q_{n / i s},
$$

where $\mathrm{Q}_{\text {is }}$ - total heat loss due to coolant cooling in pipelines of external heat networks heat insulated with traditional types of thermal insulation (mineral wool mats), Gcal/year; 
$\mathrm{Q}_{\mathrm{n} / \mathrm{is}}$ - total heat loss due to cooling of the coolant in the sections of pipelines of heating networks that do not have thermal insulation, Gcal/year.

2. The calculation of actual heat energy losses due to coolant cooling in the pipelines of the external heat networks heat insulated mineral wool mats $\mathrm{Q}_{\mathrm{is}}$, we will determine by the methodology given in the KTM 204 Ukraine 244-94: "Norms and guidelines on rationing expenses fuel and heat energy for heating residential and public buildings, as well as for household needs in Ukraine":

$$
Q_{i s}=\sum\left(q_{n}^{s} \cdot l^{s}+q_{n}^{r} \cdot l^{r}\right) \cdot n \cdot \beta \cdot 0.86 \cdot 10^{-6}, \mathrm{Gcal},
$$

where $\mathrm{q}_{\mathrm{n}}^{\mathrm{s}}, \mathrm{q}_{\mathrm{n}}^{\mathrm{r}}$ - the norm of the density of the heat flux from the surface of the supply or return insulated pipeline of the corresponding diameter, depends on the type of gasket, W/m;

$1^{\mathrm{s}}, \mathrm{l}^{\mathrm{r}}$ - length of the supply or return insulated pipeline of the corresponding diameter, $\mathrm{m}$;

$n-$ the number of hours of operation of the corresponding section of the insulated pipeline in the planned period, $\mathrm{h}$;

$\beta$ - the coefficient of local heat loss, taking into account the heat loss of reinforcement, supports and compensators.

3. The determination of heat loss for uninsulated pipelines is carried out according to the formula:

$$
Q_{n / i s}=q_{1} \cdot L \cdot n \cdot k \cdot 10^{-6}, \mathrm{Gcal},
$$

where $\mathrm{q}_{1}$ - the specific heat flux from one linear meter of an uninsulated pipeline per hour, $\mathrm{Kcal} /(\mathrm{m} \cdot \mathrm{h})$;

$\mathrm{L}$ - the length of the uninsulated pipeline, $\mathrm{m}$;

$\mathrm{n}$ - the number of hours of work per year, $\mathrm{h}$;

$\mathrm{k}$ - coefficient taking into account the difference in ambient temperature from $+25^{\circ} \mathrm{C}$.

Thermal losses at other ambient temperatures are determined by multiplying by a coefficient:

$$
k=\frac{t_{f}+t_{i n}}{25+t_{i n}},
$$

where $t_{f}-$ the actual ambient temperature; $t_{\text {in }}$ - temperature of the working bodies in a pipe or in a container.

Heat losses for a coolant temperature of 100 to $50{ }^{\circ} \mathrm{C}$ can approximately be taken with such coefficients.

Intermediate values of the norms of heat flux density determined by interpolation. 
4. Calculation of actual heat energy losses due to coolant cooling in pipelines of external heating networks provided that insulating pipelines are introduced $\mathrm{Q}_{\text {tot2 }}$, we will determine according to the methodology given in normative document ${ }^{9}$ :

$$
Q_{\text {tot } 2}=\sum\left(q_{n}^{s} \cdot l^{s}+q_{n}^{r} \cdot l^{r}\right) \cdot n \cdot \beta \cdot k_{2} \cdot 0.86 \cdot 10^{-6}, \mathrm{Gcal},
$$

where $\mathrm{k}_{2}$ - coefficient taking into account changes in the norms of heat flux density when using a heat-insulating layer of polyurethane foam.

\section{Mathematical models for evaluating the effectiveness of energy-saving means in the consumption of thermal energy}

\subsection{Determination of energy efficiency from reducing heat loss through the enclosing structures building}

The initial data for the calculation are determined by the results of fullscale examination or design parameters of the building, its purpose, operating mode, climatic conditions, and standard values for the temperature of the indoor air in the buildings. The list of necessary data for the calculation are given in table 1 .

Energy expenses for heating for the heating season Q (in J) are determined using formulas (1) - (4) and the data presented in table 2-6.

After calculating the value of $\mathrm{Q}$ we set measures to reduce the heat loss of the building, using table 8 .

The energy consumption for heating during the heating season after measures to thermal modernization of the building $-\mathrm{Q}_{\mathrm{tm}}, \mathrm{J}$ are determined in the same way using formulas (1) - (4) and the data presented in table 2-6.

In the case of a decision on the installation of metal-plastic windows, the value of the heat transfer coefficient of resistance of the window, which is taken into account in formula (3), is taken in accordance with table 9.

Table 8

Measures to reduce heat loss of the building

\begin{tabular}{|c|l|l|}
\hline № & \multicolumn{1}{|c|}{ Expected Result } & \multicolumn{1}{|c|}{ Event } \\
\hline 1 & \multicolumn{1}{|c|}{3} \\
\hline 1 & $\begin{array}{l}\text { Decrease in heat losses } \\
\text { through a ceiling }\end{array}$ & $\begin{array}{l}\text { Insulation wall with facing bricks, polystyrene } \\
\text { foam boards, polystyrene foam, mineral wool. }\end{array}$ \\
\hline 2 & $\begin{array}{l}\text { Decrease in heat losses } \\
\text { through a ceiling }\end{array}$ & $\begin{array}{l}\text { Insulation of the attic floor with a layer of } \\
\text { mineral wool }\end{array}$ \\
\hline
\end{tabular}

${ }^{9}$ КТМ 204 Україна 244-94. Норми та вказівки по нормуванню витрат палива та теплової енергії на опалення житлових та громадських споруд, а також на господарсько-побутові потреби України. Київ : ЗАТ «ВІПОЛ» ДК № 15, 2011. 376 с. 
Table 8 (ending)

\begin{tabular}{|c|l|l|}
\hline 1 & \multicolumn{1}{|c|}{2} & \multicolumn{1}{|c|}{3} \\
\hline 3 & $\begin{array}{l}\text { Decrease in heat losses } \\
\text { through a floor }\end{array}$ & $\begin{array}{l}\text { Laying under the floor an additional layer of } \\
\text { mineral wool, fiberboard or chipboard }\end{array}$ \\
\hline 4 & $\begin{array}{l}\text { Decrease in heat losses } \\
\text { through window openings }\end{array}$ & $\begin{array}{l}\text { Installation of metal-plastic windows with one- } \\
\text { or two-chamber double-glazed windows, it is } \\
\text { possible to fill the chamber with argon, } \\
\text { applying an energy-saving coating to the glass }\end{array}$ \\
\hline 5 & $\begin{array}{l}\text { Decrease in heat losses } \\
\text { due to infiltration }\end{array}$ & $\begin{array}{l}\text { The use sealant of metal-plastic windows } \\
\text { shutdown of supply and exhaust ventilation } \\
\text { during the absence of people in the room, the } \\
\text { use of turbocharged boilers }\end{array}$ \\
\hline
\end{tabular}

The energy saving for heating during the heating season as a result of measures to reduce heat loss $-\Delta \mathrm{Q}$ is defined as: $\Delta \mathrm{Q}=\mathrm{Q}-\mathrm{Q}_{\mathrm{tm}}$.

3.2. Determination of energy efficiency from the introduction of thermal insulation on inner-brownies heating networks

1. The saved amount of thermal energy for the year $\Delta \mathrm{Q}$ from the introduction of thermal insulation on the thermal networks of air laying (including basements and premises) meeting the requirements for thermal resistance in accordance with current regulations (СНиП 2.04.14-88*) is determined by the formula:

$$
\Delta Q=Q_{\text {sum } 1}-Q_{\text {sum } 2},
$$

where $\mathrm{Q}_{\text {sum } 1}$ - total heat loss due to cooling of the coolant in the pipelines of external thermal networks insulated with thermal insulation with thermal resistance that does not meet the requirements of current regulations and pipelines without thermal insulation, Gcal/year;

$\mathrm{Q}_{\text {sum2 }}$ - total heat losses due to cooling of the heat carrier in pipelines of external thermal networks heat-insulated under the condition of introduction of thermal insulation on thermal networks of an air lining corresponding to requirements in thermal resistance of the operating regulatory documentation, Gcal/year.

The value of $\mathrm{Q}_{\text {sum1 }}$ consists of 2 values:

$$
Q_{\text {sum } 1}=Q_{\text {sum } 1}^{n / i s}+Q_{\text {sum } 1}^{i s},
$$

where $\mathrm{Q}^{\mathrm{n} / \mathrm{is}}$ sum1 - the heat loss due to cooling of the coolant in the pipelines of external thermal networks that do not have thermal insulation;

$\mathrm{Q}_{\text {sum } 1}^{\text {is }}$ - the heat loss due to cooling of the coolant in the pipelines of the external heating networks isolated by thermal insulation from thermal resistance that does not meet the requirements of the current regulatory documentation. 
Table 9

The values of the coefficient of resistance to heat transfer of the main types of metal-plastic windows

\begin{tabular}{|l|l|c|c|}
\hline № & Characteristics of double-glazed windows & $\begin{array}{c}\text { Designation of the } \\
\text { characteristics of } \\
\text { double-glazed } \\
\text { windows }\end{array}$ & $\begin{array}{c}\text { Heat transfer } \\
\text { resistance } \\
\text { coefficient, } \\
\left(\mathrm{m}^{2} \cdot \mathrm{K}\right) / \mathrm{W}\end{array}$ \\
\hline 1 & Single-chamber & $4-16-4$ & 0.32 \\
\hline 2 & Single-chamber with argon & $4-16-4 \mathrm{Ar}$ & 0.34 \\
\hline 3 & Single-chamber with energy-saving coating & $4-16-4 \mathrm{i}$ & 0.59 \\
\hline 4 & $\begin{array}{l}\text { Single-chamber with energy-saving coating } \\
\text { with argon }\end{array}$ & $4-16-4 \mathrm{Ar}$ & 0.66 \\
\hline 5 & Two-chamber & $4-12-4-12-4$ & 0.49 \\
\hline 6 & Two-chamber with argon & $4-12-4-12-4 \mathrm{Ar}$ & 0.52 \\
\hline 7 & Two-chamber with energy-saving coating & $4-12-4-12-4 \mathrm{i}$ & 0.72 \\
\hline 8 & $\begin{array}{l}\text { Two-chamber with energy-saving coating } \\
\text { with argon }\end{array}$ & $4-12-4-12-4 \mathrm{i} \mathrm{Ar}$ & 0.75 \\
\hline
\end{tabular}

2. Determine the value of $\mathrm{Q}_{\text {sum1 }}^{\mathrm{n} \text { is }}$ using the formula:

$$
Q_{\text {sum } 1}^{n / i s}=2 \cdot \pi \cdot r_{e x}^{2} \cdot L \cdot\left(t_{1}-t_{e n}\right) \cdot \alpha \cdot n,
$$

where $r_{e x}$ - the outer radius of the pipe without insulation, $m$;

$\mathrm{L}$ - the length of the uninsulated part of the heat pipe, $\mathrm{m}$;

$\mathrm{t}_{1}$ - the average temperature of the coolant (for the pipes of the heating system is taken according to the temperature schedule at the average temperature of the outside air for the heating period, for the pipes of the hot water supply system we take $\left.+55{ }^{\circ} \mathrm{C}\right),{ }^{\circ} \mathrm{C}$;

$\mathrm{t}_{\mathrm{en}}$ - average ambient temperature (surrounding the heat pipe, in the premises is measured during the audit and is approximately accepted for the entire calculation period), ${ }^{\circ} \mathrm{C}$;

$\alpha$ - heat transfer coefficient from the surface of the pipe into the air, $\mathrm{W} /\left(\mathrm{m}^{2} \cdot \mathrm{K}\right)$;

$\mathrm{n}-$ the number of hours of operation of the corresponding non-insulated section of the pipeline in the planned period (for example, year), hours.

The coefficient $\alpha$ is determined by the formula ${ }^{10}$ :

${ }^{10}$ Гром А.С., Худенко А.А., Азутов В.П. Методика визначення нераціонального (неефективного) використання паливно-енергетичних ресурсів. Київ : Держінспекція з енергозбереження, 2006. 134 с. 


$$
\alpha=8+0.04 \cdot t_{n}+6 \cdot \sqrt{V},
$$

where $t_{n}$ - the surface temperature of the pipe (for the pipelines of the heating system it is taken as the temperature schedule at the average outdoor temperature air for the heating period, for the pipelines of the hot water supply we take $\left.55^{\circ} \mathrm{C}\right),{ }^{\circ} \mathrm{C}$;

$\mathrm{V}$ - air movements velocity (in rooms, usually values fluctuate within $0.2-0.3 \mathrm{~m} / \mathrm{s}$, but should not exceed $\left.1.0^{11}\right), \mathrm{m} / \mathrm{s}$.

3. Determine the value of $\mathrm{Q}^{\text {is }}{ }_{\text {sum1 }}$ using the formula:

$$
Q_{\text {sum } 1}^{i s}=L \cdot n \cdot \frac{\left(t_{1}-t_{e n}\right)}{R} \cdot 10^{-6},
$$

where $\mathrm{n}-$ is the number of hours of operation of the corresponding isolated section of the pipeline in the planned period (for example, year), $\mathrm{h}$;

$\mathrm{R}$ - the sum of the thermal resistances on the path of the heat flux from the coolant to the environment, $\left(\mathrm{m} \cdot \mathrm{h} \cdot{ }^{\circ} \mathrm{C}\right) / \mathrm{Kcal}$.

$$
R=\frac{\left(t_{f 1}-t_{e n}\right)}{q_{f 1}},
$$

where $\mathrm{t}_{\mathrm{f} 1}$-the actual temperature of the coolant during the audit, ${ }^{\circ} \mathrm{C}$;

$\mathrm{q}_{\mathrm{f} 1}$ - the actual linear density of the heat flux from $1 \mathrm{~m}$ of the length of the pipeline, Kcal/ running m:

$$
q_{f 1}=2 \cdot \pi \cdot r_{i s}^{2} \cdot\left(t_{f 2}-t_{e n}\right) \cdot \alpha,
$$

where $\mathrm{r}_{\text {is }}$ - the external insulation radius on the pipeline, $\mathrm{m}$;

$\mathrm{t}_{\mathrm{f} 2}$ - the actual temperature on the surface of the insulating layer during the audit, ${ }^{\circ} \mathrm{C}$;

$\alpha$ - the heat transfer coefficient from the surface of the pipe insulation into the air:

$$
\alpha=8+0.04 \cdot t_{f 2}+6 \cdot \sqrt{V},
$$

4. Determine the total heat loss due to cooling of the coolant in the pipelines of the external heat networks insulated, provided that thermal insulation is introduced on the heat networks of the air duct corresponding to the requirements in the thermal resistance of the current regulatory documentation using the formula:

11 ДСН 3.3.6.042-99. Санітарні норми мікроклімату виробничих приміщень. URL: http://sop.zp.ua/norm_dsn_1999_3_3_6_042-99_02_ua.php. 


$$
Q_{\text {sum } 2}=\sum\left(q_{n} \cdot l\right) \cdot n \cdot k \cdot 0.86 \cdot 10^{-6},
$$

where $\mathrm{q}_{\mathrm{n}}$ - the norm of the density of the heat flux from the surface of an insulated pipeline of the corresponding diameter, depends on the type of gasket, diameter and temperature of the coolant, $\mathrm{W} / \mathrm{m}$;

1 - the length of the insulated pipeline of the corresponding diameter, $\mathrm{m}$;

$\mathrm{n}$ - the number of hours of operation of the corresponding section of the insulated pipeline in the planned period, $\mathrm{h}$;

$\mathrm{k}$ - coefficient taking into account the difference in ambient temperature from $+5{ }^{\circ} \mathrm{C}$.

Heat losses at other ambient temperatures are determined by multiplying by a coefficient:

$$
k=\frac{t_{f}-t_{\text {in }}}{5+t_{\text {in }}},
$$

where $\mathrm{t}_{\mathrm{f}}-$ the actual ambient temperature, ${ }^{\circ} \mathrm{C}$;

$\mathrm{t}_{\mathrm{in}}$ - temperature of the working solid in a pipe or in a container, ${ }^{\circ} \mathrm{C}$.

Heat losses for a coolant temperature of 100 to $50{ }^{\circ} \mathrm{C}$ can approximately be taken with such coefficients. Intermediate values of heat flux density norms are determined by interpolation.

\subsection{Determination of energy efficiency from the introduction of automated control systems for the thermal conditions of the premises}

The initial data for the calculation are determined by the results of a full scale survey or design parameters of the building, its purpose, operation mode and other data specified in table 9.

Energy resources savings during the heating season as a result of the introduction of the optimal temporary temperature regime $-\Delta \mathrm{Q}$ is determined by the formula ${ }^{12}$ :

$$
\Delta \mathrm{Q}=\sum_{i=1}^{3}\left(\Delta t_{i} \cdot \tau_{i} \cdot\left(\sum_{j=1}^{4} 3600 \cdot k_{j} \cdot F_{j}+c \cdot m_{\mathrm{inf}}\right)\right),
$$

where $\Delta t_{i}-$ the recommended value of the decrease in temperature in the room in the absence of people, is taken according to table $10,{ }^{\circ} \mathrm{C}$;

$\mathrm{k}_{1}, \mathrm{k}_{2}, \mathrm{k}_{3}, \mathrm{k}_{4}$ - heat transfer coefficients of the external walls, ceilings, windows and floor, respectively, determined by the formula $(3), \mathrm{W} /\left(\mathrm{m}^{2} \mathrm{~K}\right)$;

12 Сухонос М.К., Полив'янчук А.П., Коваленко Ю.Л. та ін. Створення та апробація концепції комплексного оцінювання енергетичної, екологічної та економічної ефективності заходів 3 енергозбереження в будівлях. Комунальне господарство міст. Серія «Економічні науки». 2018. Вип. 6 (145). С. 33-37. DOI: 10.33042/2522-1809-2018-6-145-33-37. 
Initial data for calculating the effectiveness of energy conservation measure

\begin{tabular}{|c|c|c|c|}
\hline № & The name of the parameter & Unit & Value \\
\hline 1 & The total area of the walls & $\mathrm{m}^{2}$ & $F_{w}$ \\
\hline 2 & The thickness of the i-th layer of the walls & $\mathrm{m}$ & $1_{\mathrm{wi}}$ \\
\hline 3 & Material of the i-th layer of walls & - & - \\
\hline 4 & The total area of window openings & $\mathrm{M}^{2}$ & $F_{\text {win }}$ \\
\hline 5 & The thickness of the glass in the window openings & $\mathrm{m}$ & $1_{\text {wini }}$ \\
\hline 6 & The number of glasses in the window openings & pcs & - \\
\hline 6 & The total area of attic floors & $\mathrm{m}^{2}$ & $\mathrm{~F}_{\mathrm{af}}$ \\
\hline 7 & The thickness of the i-th layer of attic floors & $\mathrm{m}$ & $l_{\text {afi }}$ \\
\hline 8 & Material of the i-th layer of attic floors & - & - \\
\hline 9 & Total floor area & $\mathrm{m}^{2}$ & $F_{f}$ \\
\hline 10 & The thickness of the i-th layer of floors & $\mathrm{m}$ & $1_{\mathrm{fi}}$ \\
\hline 11 & Material of the i-th layer of floors & & \\
\hline 12 & $\begin{array}{l}\text { Total time for the heating season, the short-term } \\
\text { absence of people in the room with a duration of one } \\
\text { interval from } 8 \text { to } 16 \text { hours }\end{array}$ & hours & $\tau_{1}$ \\
\hline 13 & $\begin{array}{l}\text { Total time for the heating season, the medium-term } \\
\text { absence of people in the room with a duration of one } \\
\text { interval from } 16 \text { to } 64 \text { hours }\end{array}$ & hours & $\tau_{2}$ \\
\hline 14 & $\begin{array}{l}\text { Total time for the heating season, the long-term } \\
\text { absence of people in the room with a duration of one } \\
\text { interval of more than } 64 \text { hours }\end{array}$ & hours & $\tau_{3}$ \\
\hline 15 & The height of the ceilings in the room & $\mathrm{m}$ & $\mathrm{h}$ \\
\hline
\end{tabular}

$F_{i}$ - the area of elements of enclosing structures, including external walls, windows, floors, and ceilings; it is taken in accordance with the table $9, \mathrm{~m}^{2}$;

c - the mass heat capacity of air; in the calculations, the value $\mathrm{c}=1005 \mathrm{~J} /(\mathrm{kg} \mathrm{K})$ is approximately taken;

$\mathrm{m}_{\mathrm{inf}}$ - the mass of air entering the room with infiltration per hour is determined by the formula (4), $\mathrm{kg}$;

$\tau_{1}, \tau_{2}, \tau_{3}$ - the total duration of the short-term, mid-term and long-term absence of people in the room during the heating season, respectively, h; accepted in accordance with the table 9. 
The recommended value of lowering the temperature in the room in the absence of people

\begin{tabular}{|c|l|c|}
\hline № & \multicolumn{1}{|c|}{ One-time duration of absence of people, $\mathrm{h}}$. & $\Delta \mathrm{t}_{\mathrm{i}},{ }^{\circ} \mathrm{C}$ \\
\hline 1 & short-term from 8 to 16 hours & 3 \\
\hline 2 & medium-term from 16 to 64 hours & 4 \\
\hline 3 & Long-term, more than 64 hours & 5 \\
\hline
\end{tabular}

Energy resources savings during the heating season as a result of the introduction of the optimal temporary temperature regime $\Delta \mathrm{Q}$ can be expressed in $\mathrm{kW} \mathrm{h}$. Using the ratio of $1 \mathrm{~J} \approx 0.27810^{-6} \mathrm{~kW} \mathrm{~h}$.

\section{Mathematical model for a comprehensive assessment of the energy-saving measures effectiveness}

The mathematical model was created with the aim of multi-criteria environmental, energy - economic evaluation of the effectiveness of energy saving events implemented in the system of "producer-supplier-consumer" of thermal energy. The essence of the model lies in the fact that the overall effectiveness of these events is considered as a 3-component vector $\mathrm{E}$, whose components are energy $-\mathrm{E}_{\mathrm{I}}$, environmental $-\mathrm{E}_{\mathrm{II}}$ and economic $-\mathrm{E}_{\mathrm{III}}$ effects from their implementation:

$$
E=\left|E_{I}, E_{I I}, E_{I I I}\right|
$$

In this case, the performance criteria are:

- energy effect $\mathrm{E}_{\mathrm{I}}$ : absolute $-\Delta \mathrm{Q}(\mathrm{kW} \cdot \mathrm{h})$ and relative $-\delta \mathrm{Q}(\%)$ of the value of the saved amount of thermal energy for the heating period, which are determined by the formulas:

$$
\Delta Q=Q_{\text {sum } 1}-Q_{\text {sum } 2},
$$

where $\mathrm{Q}_{\text {sum1 }}$ and $\mathrm{Q}_{\text {sum2 }}$ are the total heat losses through the building envelope for the heating period before and after the introduction of energysaving measures, respectively, $\mathrm{kW} \cdot \mathrm{h}$;

$$
\delta Q=\frac{Q_{\text {sum } 1}-Q_{\text {sum } 2}}{Q_{\text {sum } 1}} \cdot 100 \%,
$$


- ecological effect $\mathrm{E}_{\mathrm{II}}$ : mass (volume) of saved fuel $-\Delta \mathrm{M}_{\text {fuel }}(\mathrm{kg})$ $\left(\Delta \mathrm{V}_{\text {fuel }}\left(\mathrm{m}^{3}\right)\right.$, reduction in the mass of emissions of greenhouse gases, in particular $\mathrm{CO}_{2}$ and pollutants $-\Delta \mathrm{M}_{\mathrm{pol}}(\mathrm{kg})$ :

$$
\Delta M_{\text {fuel }}=3.6 \cdot \frac{\Delta \mathrm{Q}}{\mathrm{Q}_{\text {fuel }}},
$$

where $\mathrm{Q}_{\text {fuel }}$ is the net calorific value of fuel, $\mathrm{MJ} / \mathrm{kg}$ (natural gas: $\mathrm{Q}_{\text {fuel }}=36.7 \mathrm{MJ} / \mathrm{kg}$ ).

$$
\Delta V_{\text {fuel }}=\frac{\Delta \mathrm{M}_{\text {fuel }}}{\rho_{\text {fuel }}}, \mathrm{m}^{3},
$$

where $\rho_{\text {fuel }}$ is the density of the fuel, $\mathrm{kg} / \mathrm{m}^{3}$ (for natural gas $\left.\rho_{\text {fuel }}=0.73 \mathrm{~kg} / \mathrm{m}^{3}\right)$.

$$
\Delta M_{p o l}=3.6 \cdot 10^{-3} \cdot K_{p o l} \cdot \Delta \mathrm{Q},
$$

where $\mathrm{K}_{\mathrm{pol}}$ is the pollutant emission coefficient, $\mathrm{g} / \mathrm{GJ}\left(\mathrm{K}_{\mathrm{CO} 2}=58.7 \mathrm{~kg} / \mathrm{GJ}\right.$; $\mathrm{K}_{\mathrm{NOx}}=0.064 \mathrm{~kg} / \mathrm{GJ}$ );

- economic effect $\mathrm{E}_{\mathrm{III}}$ : reduction of the charge for the amount of heat energy consumed during the heating period $-\Delta \mathrm{C}_{\text {heat }}(\mathrm{UAH})$ and for fuel $\Delta \mathrm{C}_{\text {fuel }}(\mathrm{UAH})$ :

$$
\Delta C_{\text {heat }}=9.6 \cdot 10^{-4} \cdot c_{\text {heat }} \cdot \Delta \mathrm{Q},
$$

where $c_{\text {heat }}$ is the cost of a unit of thermal energy according to established tariffs, UAH/Gcal.

$$
\Delta C_{\text {fuel }}=10^{-3} \cdot c_{\text {fuel }} \cdot \Delta \mathrm{V}_{\text {fuel }},
$$

where $c_{\text {fuel }}$ is the cost of fuel in accordance with established tariffs, $\mathrm{UAH} /$ ton or $\mathrm{UAH} /$ thousand $\mathrm{m}^{3}$.

Experimental development of a mathematical model for a comprehensive assessment of the effectiveness of energy saving measures was carried out on the basis of a full-scale object of a complex technical system, which was selected as the Communal Institution "Kharkov Palace of Children and Youth Creativity of the Kharkiv City Council of the Kharkov Region" (CI KhPCYC) with the building 1993 building (Fig. 1). 


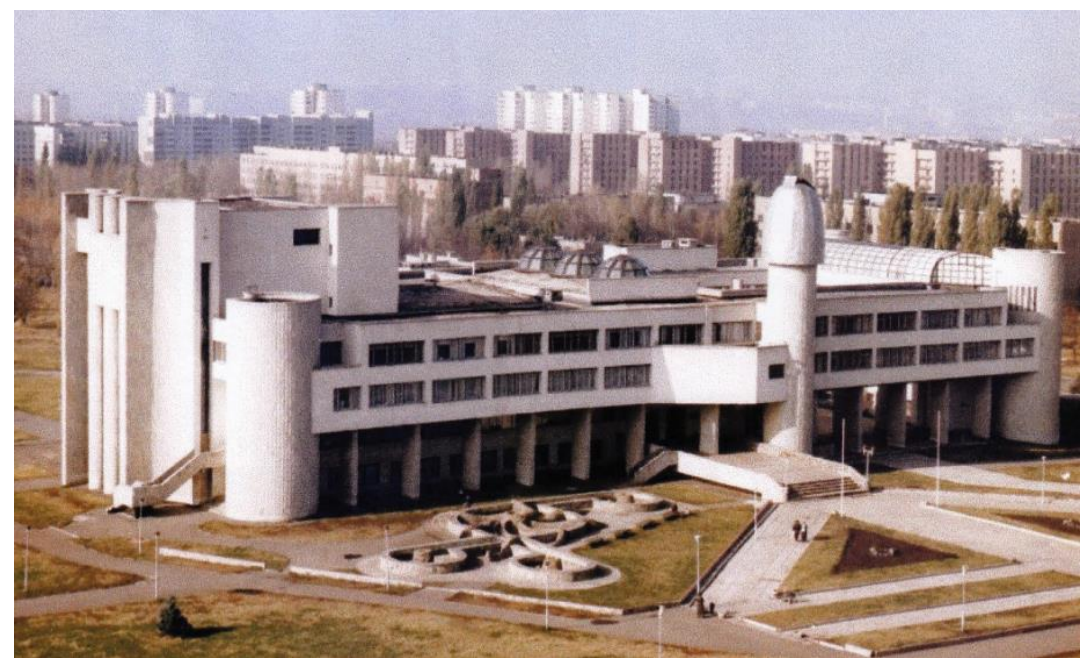

Fig. 1. General view of the building of CI KhPCYC

Based on the analysis of technical documentation, the results of external and internal surveys of the natural object, averaged data on the monthly and annual heat consumption of the building, a complex of energy-saving measures is proposed, which includes:

- event No 1 - thermal modernization of the fencing facilities, which provides fulfillment works for the application of heat-insulating materials to the fencing facilities in order to increase their heat transfer resistance to levels that meet the requirements of modern regulatory documents;

- event No 2 - implementation of the "smart home" technology for controlling the heating conditions of premises, which provides for the use of the HERZ Smart Comfort system ${ }^{13}$ or its analogue for the automated regulation of the thermal conditions of the building's premises taking into account their actual need for comfortable thermal energy;

- event No 3 - thermal modernization of individual heat items (IHI) of the building, which provides for the improvement of thermal insulation of pipelines and IHI equipment in order to increase their heat transfer resistance to levels that meet the requirements of modern regulatory documents;

- event No 4 - the use of an additional alternative source of heat supply a solar system, which provides for the use of 180 solar collectors $^{14}$ for

13 HERZ Smart Comfort: дистанционное управление комфортом дома. URL: https://go-gl.com/LJsyXhXM.

14 Плоскі сонячні колектори Logasol SKT 1.0. Будерус Україна. URL: https://go-gl.com/TWSjt74P. 
converting solar thermal energy into thermal energy of a heat carrier, ensuring the functioning of heating systems and hot heat consumption of the CI KhPCYC building and, if necessary, other buildings;

- event No 5 - the use of energy-efficient gas condensing boilers ${ }^{15}$ as the main source of heat supply, which provides for the replacement of obsolete gas boilers in the building's heating system with modern gas condensing boilers with increased efficiency.

The environmental, energy and economic indicators characterizing the current state of the building of the CI KhPCYC were used as initial data for evaluating the effectiveness of the proposed energy saving measures (table 11).

Table 11

Input data for a comprehensive assessment of the effectiveness of energy conservation measures No. 1-5

\begin{tabular}{|c|c|c|c|c|c|c|}
\hline \multirow{3}{*}{\multicolumn{2}{|c|}{$\begin{array}{c}\text { Period } \\
\text { observation }\end{array}$}} & \multicolumn{5}{|c|}{$\begin{array}{l}\text { Indicators that characterize the current state } \\
\text { object of research }\end{array}$} \\
\hline & & \multirow{2}{*}{$\begin{array}{c}\text { Energetic } \\
\mathrm{Q}_{0}, \\
\text { Gcal }\end{array}$} & \multicolumn{3}{|c|}{ Ecological } & \multirow{3}{*}{$\begin{array}{c}\text { Economic } \\
\mathrm{C}_{\text {heat }}, \\
\text { thousand } \\
\text { UAH }\end{array}$} \\
\hline & & & & & & \\
\hline \multirow{12}{*}{$\begin{array}{l}\text { The } \\
\text { month of } \\
\text { the year }\end{array}$} & 1 & 429.6 & 53.2 & 103.5 & 0.113 & \\
\hline & 2 & 378.6 & 47.9 & 93.1 & 0.102 & 724.9 \\
\hline & 3 & 241.2 & 30.5 & 59.3 & 0.065 & 461.8 \\
\hline & 4 & 104.2 & 13.2 & 25.6 & 0.028 & 199.5 \\
\hline & 5 & 41.8 & 5.3 & 10.3 & 0.011 & 80.0 \\
\hline & 6 & 10.6 & 1.3 & 2.6 & 0.003 & 20.3 \\
\hline & 7 & 0 & 0.0 & 0.0 & 0.000 & 0.0 \\
\hline & 8 & 1.7 & 0.2 & 0.4 & 0.000 & 3.3 \\
\hline & 9 & 21.1 & 2.7 & 5.2 & 0.006 & 40.4 \\
\hline & 10 & 128.3 & 16.2 & 31.6 & 0.035 & 245.7 \\
\hline & 11 & 286.2 & 36.2 & 70.4 & 0.077 & 548.0 \\
\hline & 12 & 226.7 & 28.7 & 55.8 & 0.061 & 434.1 \\
\hline \multicolumn{2}{|c|}{ Year } & 1870.3 & 236.7 & 460.0 & 0.504 & 3581.1 \\
\hline
\end{tabular}

${ }^{15}$ Газовые конденсационные котлы Logamax plus GB112 29, 43 и 60 кBт. URL: https://go-gl.com/jjj1hcyTJ. 
The results of a comprehensive evaluation of the effectiveness of energy saving measures No. 1-5 using the mathematical model presented above showed the following (Fig. 2):

- event No 1 is the most effective of the recommended energy saving measures, which allows to reduce the loss of thermal energy of the heat consumption system during the heating period and to obtain such an annual effect: energy: saving of thermal energy - 908.8 Gcal or $48.5 \%$; environmental: reduction of natural gas consumption -115 thousand $\mathrm{m}^{3}$, reduction of $\mathrm{CO}_{2}$ and $\mathrm{NO}_{\mathrm{x}}$ emissions into the atmosphere - 223.5 tons and 0.245 tons, respectively; economic: reduction of heating fees 1740.2 thousand UAH;

- event No 2 allows to reduce the heat loss of the heat consumption system during the heating period and obtain the following annual effect: energy: heat energy saving - $130.3 \mathrm{Gcal}$ or $7.0 \%$; environmental: reduction of natural gas consumption -16.5 thousand $\mathrm{m}^{3}$, reduction of $\mathrm{CO}_{2}$ and $\mathrm{NO}_{\mathrm{x}}$ emissions into the atmosphere -32.0 tons and 0.035 tons, respectively; economic: reduction of heating fees -249.5 thousand UAH;

- event No 3 allows you to reduce the heat loss of the heat consumption system during the year and get such an annual effect: energy: saving heat energy - $118.7 \mathrm{Gcal}$ or $6.3 \%$; environmental: reduction of natural gas consumption -15.0 thousand $\mathrm{m}^{3}$, reduction of $\mathrm{CO}_{2}$ and $\mathrm{NO}_{\mathrm{x}}$ emissions into the atmosphere - 29.4 tons and 0.032 tons, respectively; economic: reduction of payment for thermal energy - 227.1 thousand UAH;

- event No 4 allows you to further increase the amount of heat energy of the heat supply system during the year and get such an annual effect: energy: additional amount of heat energy $-376.7 \mathrm{Gcal}$ or $20.2 \%$, from which it can be used: building CI KhPCYC $-212.3 \mathrm{Gcal}$ or $11.4 \%$, other buildings (from May to September) $-164.4 \mathrm{Gcal}$ or $8.8 \%$; at the same time, the demand of CI KhPCYC in heat energy is provided: in the period from May to September - by $100 \%$, in the heating period - by $2.8 \ldots 35.6 \%$; environmental: reduction of natural gas consumption -47.7 thousand $\mathrm{m}^{3}$, reduction of $\mathrm{CO}_{2}$ and $\mathrm{NO}_{\mathrm{x}}$ emissions into the atmosphere $-92.6 \mathrm{t}$ and $0.101 \mathrm{t}$, respectively; economic: reduction of payment for thermal energy 721.3 thousand $\mathrm{UAH}$; at the same time, the estimated payback period of the event is 5 years; if necessary, the heating capacity of the solar system can be increased by 2.3 times - up to $880 \mathrm{Gcal} / \mathrm{year}$, if you use the roof of building B to accommodate an additional quantity of 240 solar collectors;

- event No 5 allows you to reduce the consumption of natural gas to obtain the right amount of thermal energy during the year and get such an annual effect: environmental: reduce the consumption of natural gas 80.0 thousand $\mathrm{m}^{3}$; economic: reduction of fuel charges -340.4 thousand $\mathrm{UAH}$; while the estimated payback period of the event is 8.3 years. 

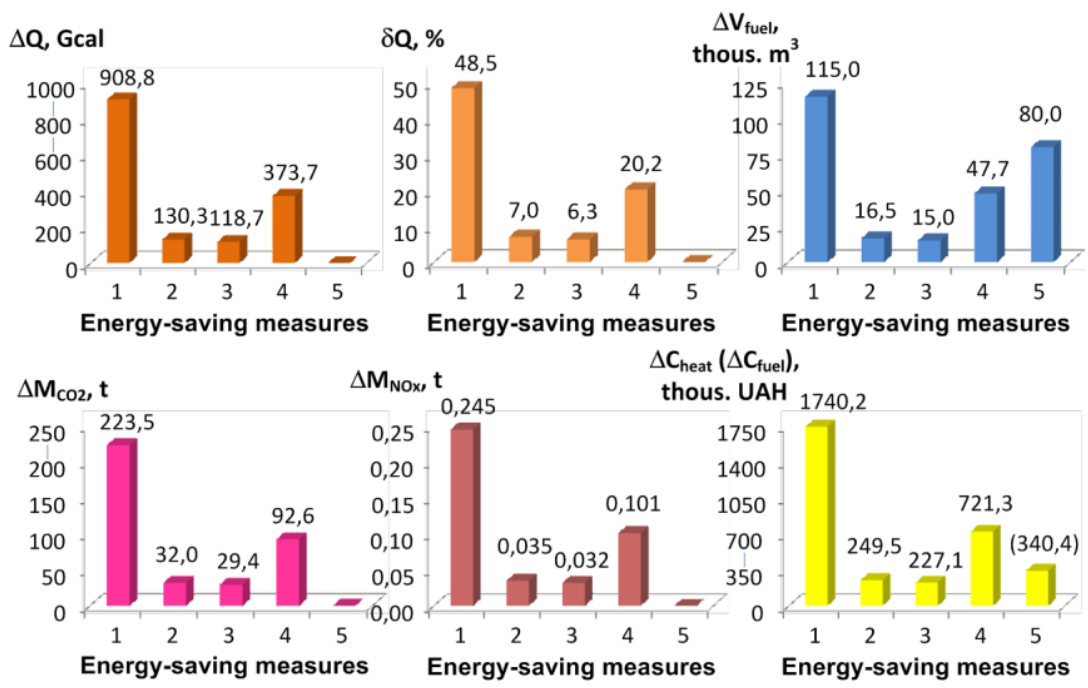

Fig. 2. The results of a comprehensive assessment

of the effectiveness of energy saving measures No. 1-5 by indicators of energy, environmental and economic effects

Thus, in the course of research, the selected full-scale object demonstrated the practical suitability of the mathematical model for a comprehensive assessment of the effectiveness of energy conservation measures recommended for the complex technical system "producersupplier-consumer" of thermal energy.

\section{CONCLUSIONS}

Mathematical models have been developed to assess the effectiveness of energy-saving measures in the production, transportation and consumption of thermal energy in the communal sector. The following energy saving measures were considered: in the production of thermal energy: the use of alternative sources of heat supply - a heat pump, a heliosystema, gas condensing boilers; when transporting thermal energy: the introduction of pre-insulated pipes of external heating networks instead of pipelines in traditional insulation or pipelines without insulation, using thermal energy, thermal modernization of building envelopes and individual heating units of buildings, the use of automated control systems for the thermal conditions of rooms.

A mathematical model has been created for a comprehensive assessment of the environmental - energy and economic efficiency of the complex technical system "producer-supplier-consumer" of thermal energy according to the criteria: energy effect, which is characterized by absolute and relative 
reduction in monthly and annual volume of thermal energy consumption by the object of study; environmental effect, which is characterized by indicators: reduction of monthly and annual fuel consumption by the building heat supply system, reduction of emissions of greenhouse gases, in particular $\mathrm{CO}_{2}$, and pollutants, in particular $\mathrm{NO}_{\mathrm{x}}$, in the production of thermal energy; economic effect, which is characterized by indicators of monthly and annual decrease in fees for the use of thermal energy and fuel as an object of research.

The practical suitability of the created mathematical models was confirmed in the course of studies of the effectiveness of energy-saving measures recommended for implementation in the communal institution "Kharkov Palace of Children and Youth Creativity of the Kharkov City Council of the Kharkov Region". This educational establishment was considered as a full-scale object for studies of the complex technical system "producer-supplier-consumer" of thermal energy. In the course of research, a comprehensive assessment of the energy, environmental and economic efficiency of 5 energy-saving measures was carried out: in the production of thermal energy: the use of alternative sources of heat supply - a heliosystema and gas condensing boilers with efficiency; with the consumption of thermal energy, thermal modernization of fencing structures and individual heating points of the building, control of thermal modes of premises using the HERZ Smart Comfort automated system.

\section{SUMMARY}

The work is devoted to solving the urgent scientific problem of creating a theoretical basis for a comprehensive assessment of energy, environmental and economic efficiency of energy saving measures in the areas of communal heat supply and heat consumption. The purpose of the work was to create and confirm the practical applicability of mathematical models for a comprehensive assessment of the effectiveness of energy conservation measures recommended for the implementation in the complex technical system "producer-supplier-consumer" of thermal energy in the communal scope. To achieve this goal, the following tasks were solved:

1) the development of mathematical models for assessing the energy efficiency of energy-saving measures that are implemented at facilities that produce, transport and use thermal energy in the communal scope;

2) the creation of a mathematical model for a comprehensive assessment of the effectiveness of energy-saving measures according to the criteria of energy, environmental and economic effects;

3) confirmation of the practical suitability of the developed mathematical models in the course of studies of a full-scale object of the complex technical system "producer-supplier-consumer" of thermal energy. 
Mathematical models have been developed to assess the energy efficiency of measures: the use of alternative sources of heat supply, the introduction of heat pre-insulated pipes of external heating networks, thermal modernization of fencing structures and individual heating units of buildings, etc. A mathematical model has been created for a comprehensive assessment of the environmental-energy and economic efficiency of the complex technical system "producer-supplier-consumer" of thermal energy according to the criteria: the energy effect, which is characterized indicators by absolute and relative reduction in the monthly and annual volume of thermal energy consumption by the object of study; environmental effect, which is characterized by indicators: reduction of monthly and annual volumes fuel consumption by the building heat supply system, reduction of emissions in atmosphere of greenhouse gases, in particular $\mathrm{CO}_{2}$, and pollutants, in particular $\mathrm{NO}_{x}$, in the production of thermal energy; economic effect, which is characterized by indicators of monthly and annual decreases. The practical suitability of the created mathematical models was confirmed in the course of studies of the efficiency of energy-saving measures recommended for implementation in the communal institution the "Kharkiv Palace of Children and Youth Creativity of the Kharkiv City Council of the Kharkiv Region", which was considered as a full-scale object for studies of the complex technical system "manufacturer-supplier-consumer" of thermal energy in the communal scope.

\section{REFERENCES}

1. Варламов Г.Б., Любчик Г.М., Маляренко В.А. Теплоенергетичні установки та екологічні аспекти виробництва енергії : підручник. Київ : ІВЦ «Видавництво «Політехніка», 2003. 232 с.

2. Polyvianchuk A., Belousov I., Semenenko R. Development and implementation methods multicriteria evaluation of efficiency energy saving activities in the field of heat supply. Modern engineering research: topical problems, challenges and modernity : Collective monograph. Riga : Izdevnieciba «Baltija Publishing», 2020. P. 370-396. DOI: 10.30525/9789934-588-47-1.17.

3. ДСТУ-Н Б В.1.1-27: 2010. Будівельна кліматологія. [Чинний від 2011-11-01]. Київ : Мінрегіонбуд України, 2011. 127 с.

4. ДБН В.2.6-31: 2016. Теплова ізоляція будівель. [Чинний від 2017-04-01]. Київ : Мінрегіон України, 2017. 31 с.

5. Исаченко В.П., Осипова А.С., Сукомел В.А. Теплопередача : учебник для вузов. Москва : Энергия, 1975. 488 с.

6. ДСТУ Б В.2.6-189: 2013. Методи вибору теплоізоляційного матеріалу для утеплення будівель. [Чинний від 2014-01-01]. Київ : Мінрегіон України, 2014. 51 с. 
7. Документация по проектированию Logatherm WPL...AR. URL: https://go-gl.com/jSjM8tGUb4.

8. КТМ 204 Україна 244-94. Норми та вказівки по нормуванню витрат палива та теплової енергії на опалення житлових та громадських споруд, а також на господарсько-побутові потреби України. Київ : ЗАТ «ВІПОЛ» ДК № 15, 2011. 376 с.

9. Гром А.С., Худенко А.А., Азутов В.П. Методика визначення нераціонального (неефективного) використання паливно-енергетичних ресурсів. Київ : Держінспекція з енергозбереження, 2006. 134 с.

10. ДСН 3.3.6.042-99. Санітарні норми мікроклімату виробничих приміщень. URL: http://sop.zp.ua/norm_dsn_1999_3_3_6_04299_02_ua.php.

11.Сухонос М.К., Полив'янчук А.П., Коваленко Ю.Л. та ін. Створення та апробація концепції комплексного оцінювання енергетичної, екологічної та економічної ефективності заходів 3 енергозбереження в будівлях. Комунальне господарство міст. Серія «Економічні науки». 2018. Вип. 6 (145). С. 33-37. DOI: 10.33042/25221809-2018-6-145-33-37.

12. HERZ Smart Comfort: дистанционное управление комфортом дома. URL: https://go-gl.com/LJsyXhXM.

13. Плоскі сонячні колектори Logasol SKT 1.0. Будерус Україна. URL: https://go-gl.com/TWSjt74P.

14. Газовые конденсационные котлы Logamax plus GB112 29, 43 и 60 кВт. URL: https://go-gl.com/jjj1hcyTJ.

Information about the authors: Polyvianchuk A. P., Doctor of Technical Sciences, Professor, O. M. Beketov National University of Urban Economy in Kharkiv

17, Marshall Bazhanov str., Kharkiv, 61002, Ukraine

Semenenko R. A.,

Graduate Student of O. M. Beketov National University of Urban Economy in Kharkiv

17, Marshall Bazhanov str., Kharkiv, 61002, Ukraine

Romanenko S. V.,

Graduate Student of O. M. Beketov National University of Urban Economy in Kharkiv 17, Marshall Bazhanov str., Kharkiv, 61002, Ukraine Semenenko L. V., Graduate Student of the National Technical University "Kharkiv Polytechnic Institute" 21, Kirpichev str., Kharkiv, 61002, Ukraine 